\section{Anisimov G., Zhukov Ye., Lipovoy $\mathbf{D}$.}

\title{
AUDIT OF CATERING NETWORK STATE IN KHARKIV CITY
}

Проведено аудит мережі закладів ресторанного господарства міста Харкова (Україна) за 2013-2016 рр. Розглянуто динаміку таких показників, як кількість закладів, загальна потужність мережі, кількість закладів за типами, потужність закладів, середня кількість місць в закладах. Сформульовані основні тенденцї̈ динаміки об'єкту аудиту. Здійснено порівняння отриманих даних аудиту з нормативними вимогами $і$ даними щодо стану мереж у інших регіонах країни і світу.

Ключові слова: заклад харчування, мережа закладів, тип закладу, потужність закладу, забезпеченість населення.

\section{Introduction}

In a modern economy, public catering is in a state of continuous change. This circumstance urgently calls upon economic entities to keep the development strategy of their enterprises under constant updating. However, in this business, despite apparent instability, there are regularities. Therefore, the catering market is based on effective planning of production and sales of own production and services.

Efficiency of management of a separate food business is impossible without understanding the structural changes of the entire network. Such activities are connected with the analysis of the dynamics of the state of the network of enterprises in a specific region and the identification of the main trends in the development of this network. The relevance of the research is identification of the trends that can have a positive impact on the planning of business activities as an individual food business and the network structure of enterprises.

\section{The object of research and its technological audit}

The object of research is a network of public catering enterprises in Kharkiv (Ukraine).

Currently, it is generally accepted to consider public catering as a type of economic activity of business entities associated with the provision of services to meet nutritional needs with or without leisure [1]. Organizational and structural unit in the field of public catering, which carries out production and trade activities, is a public catering enterprise. The totality of such enterprises of all forms of ownership located in a certain administrativeterritorial unit (region, city or district) is usually called a network of catering enterprises [2].

Recent studies have confirmed that the state of the network of catering enterprises of the administrative territorial unit is directly influenced by its socio-economic environment [3]. The characteristic of such environment in Kharkiv is related to the following circumstances, which are positive for the context under consideration:

- status of the regional center;

- developed commodity production and services;
- scientific potential;

- academic and medical entry tourism;

- recreational areas within the city;

- pendulum migration from suburban areas;

- infrastructure of wholesale trade and primary processing of agricultural products.

At the same time, it should be noted that there are factors in the external environment for the research object that can have a negative impact.

To identify trends in the development of the network of catering enterprises in Kharkiv and the formation of scientifically based interpretation of them, it seems advisable to conduct an audit of the state of the network itself, and to compare the obtained audit evidence with relevant information about the world trends in the development of this branch of the real economy.

\section{The aim and objectives of research}

The aim of research is the analysis of the state and dynamics of the network of public catering establishments in Kharkiv (Ukraine).

To achieve this aim, the following tasks are formulated:

1. To conduct an audit of organizational and technical indicators of the city network of catering enterprises for 2013-2016.

2. To investigate the city's supply of food and places in the trading halls.

3. To analyze the dynamics of organizational and technical indicators of the object of audit.

4. To study the structure of the object of audit in the context of types of catering enterprises.

5. To consider the distribution of the capacities of enterprises depending on their types.

\section{Research of existing solutions of the problem}

Public catering is a large branch of the world real economy, whose products and services are in demand daily both during working hours and during leisure. For example, 800 million meals are served annually in Finland, 1.9 billion in Sweden [4], in the Lombardy region (Italy) more 
than 211 million meals a year are being implemented as institutional food [5]. The results of economic activities of public catering entities on a country-specific scale are affected both by the state of the economy in this country and by global economic trends. These aspects have been studied in detail in [6] and it is shown that in the economically developed countries there is growing interest in the services of catering enterprises. Meanwhile, the data on the structure of the enterprise network in terms of specific regions and types of enterprises are of great practical interest.

In [7-12], the state of public catering is studied on the scale of specific countries at different time periods. It is established that during the period of economic prosperity all sectors of this industry are steadily growing. Under the influence of the economic crisis, there is a decrease in the number of enterprises of all types, except for the «Restaurant» type. It should be noted that in these studies, the state of the network of catering enterprises in such administrative-territorial units as the region and the city has practically not been reflected.

In studies [7, 13-20], the state of the catering is considered on the scale of regions and cities. In these works, in addition to statistical data on the number of enterprises and the number of places, such analytical indicators as «Provision of the population with catering enterprises», «Provision by places» and «Average number of places in the enterprise» are used.

It is established in [7] that in general in Ukraine there is a weakening of the network structure and reduction affects enterprises of all types. It should be noted that, in addition to studying the number of enterprises by type, this work explored the dynamics of places in the trading halls of catering enterprises. It is established that for the entire period under study there is a decrease in the number of places in the network. At the same time, in the integral category «Cafes, snackbars, buffets», the power weakening occurred by $0.4 \%$, for the types «Canteen» and «Bars» - by 2.8 and $4.8 \%$, respectively. The author predicts positive business prospects for cafes, snackbars and buffets, as these enterprises offer consumers services similar to restaurants, but at lower prices.

In the study [21] it is shown that under the conditions of the economic crisis in the period 2006-2009, the structure of the network in Kharkiv in the context of types of catering enterprises was coordinated with the world trends of that period. The development of the network was primarily due to the increase in the share of enterprises such as «Cafe» and «Bar», offering consumers the provision of services in a democratic format. In addition, there was a tendency to consolidate existing enterprises, which manifested itself through an increase in their average capacity.
In work [22] the tendencies of development of branch in the Kharkiv region in 2010-2015 are investigated. It is established that the network of catering enterprises in the region is gradually decreasing. Reduction affects both the number of enterprises themselves, and the number of places in them. The authors made a conclusion substantiated by calculations about the presence of a significant unoccupied potential and the existence of opportunities for further growth of the network. However, the presented data refer to the Kharkiv region as a whole and the state of the Kharkiv network isn't reflected.

It should be noted that most of the work uses quantitative information obtained either by analyzing and sorting data from secondary sources [9] or from official statistical sources [7, 10-23].

The analysis of scientific publications has shown that the current state of the network of public catering enterprises in Kharkiv has been studied little and requires further research. The evidence of such audit is of great practical interest, since they can deepen the understanding of the current trends in the development of the network and will facilitate a reasonable solution when designing new catering enterprises or reconstructing existing enterprises.

\section{Methods of research}

To solve research problems, methods of systematization, modeling, comparison and generalization of information, as well as statistical and graphical methods of data analysis are used.

\section{Research results}

The network of public catering is a set of enterprises that are similar in character to the product, the uniformity of raw materials, the generality of technological processes, the material and technical base and forms of service. Audit of network of the enterprises in any region is impossible without studying the structural changes in the network for a certain period. Table 1 is a section of the catering network in Kharkiv as of 01.01 .2017 according to the data of the Department of Administrative Services and the Consumer Market of Kharkiv City Council. Fig. 1 shows the visualization of tabular data.

As can be seen from the given data, in the period under study the number of catering enterprises in Kharkiv increased by $5.2 \%$ (from 2644 units in 2013 to 2781 units in 2016). In this case, the increase has monotonous in each time interval. These data do not coincide with the observations of other researchers who showed a decrease in the number of enterprises in the networks studied by them. This discrepancy is due to the fact that the cited studies were carried out on a scale larger than the city one [7, 22].

The main indicators of the network of catering enterprises in Kharkiv for 2013-2016

Table 1

\begin{tabular}{|c|c|c|c|c|c|c|c|c|}
\hline \multirow{3}{*}{ Indicator name } & \multicolumn{8}{|c|}{ Years } \\
\hline & \multicolumn{2}{|c|}{2013} & \multicolumn{2}{|c|}{2014} & \multicolumn{2}{|c|}{2015} & \multicolumn{2}{|c|}{2016} \\
\hline & total & $\%$ by 2013 & total & $\%$ by 2013 & total & $\%$ by 2013 & total & $\%$ by 2013 \\
\hline Number of enterprises, units & 2644 & 100.0 & 2695 & 101.9 & 2744 & 103.8 & 2781 & 105.2 \\
\hline Capacity, thousand seats & 123.8 & 100.0 & 125.3 & 101.2 & 126.9 & 102.5 & 125.7 & 101.5 \\
\hline Average power, seats & 46.8 & 100.0 & 46.5 & 99.3 & 46.2 & 98.7 & 45.2 & 96.5 \\
\hline
\end{tabular}




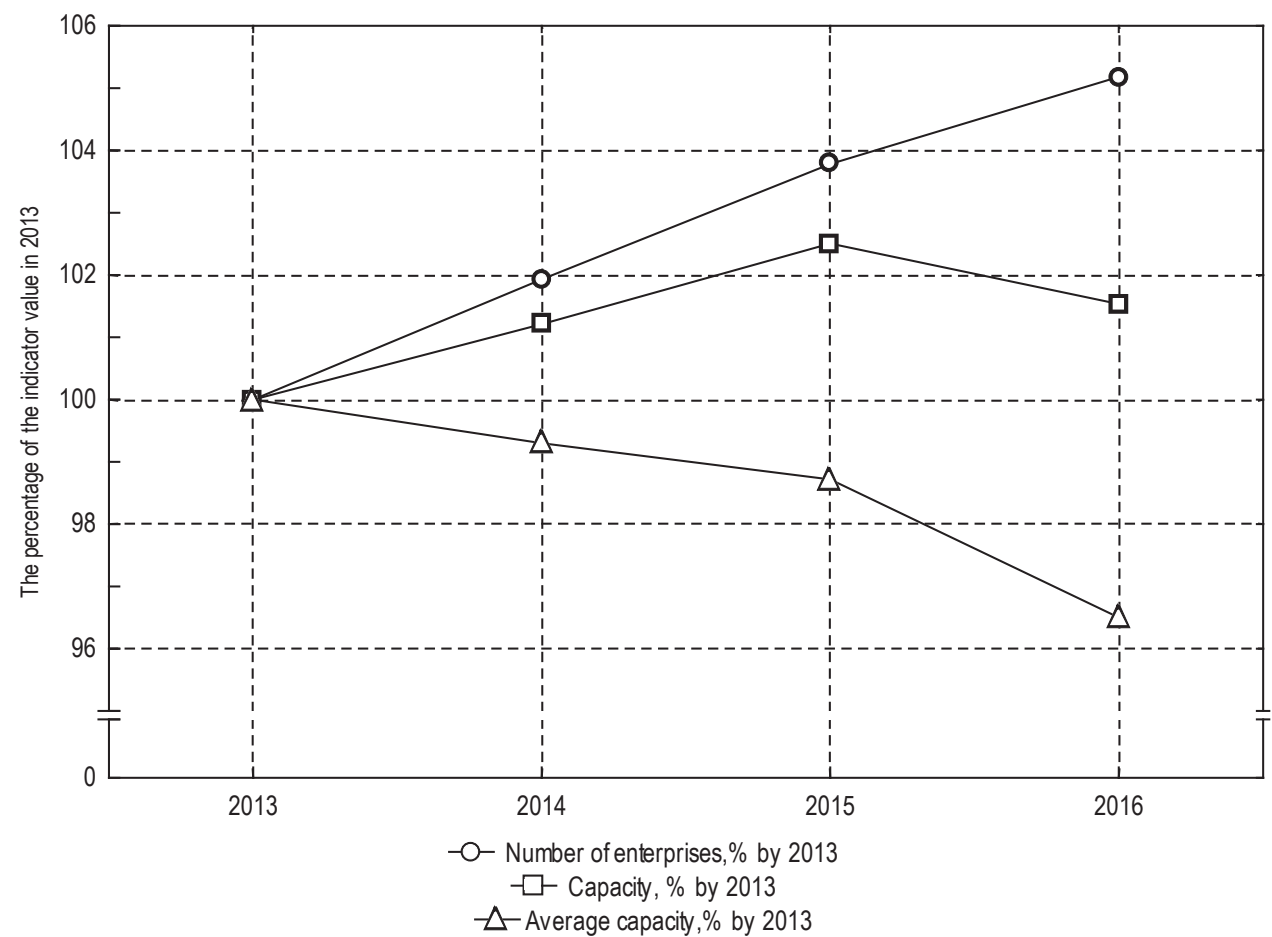

Fig. 1. Dynamics of the main indicators of the network of catering enterprises in Kharkiv for 2013-2016

It can be assumed that at present two trends appear for the audit object:

1) weakening of the network of catering enterprises in the districts of the region;

2) enlargement of the network in the regional center.

At the same time, an increase in the number of enterprises in the regional center does not compensate for their reduction in the Kharkiv region as a whole, as noted in the study [22].

According to statistical data, the population of Kharkiv as of 01.01.2017 was 1447881 people [24]. The actual supply of food for 10 thousand people by enterprises is 19 objects, which is three times more than this indicator for the region [22]. At the same time, in the countries of the European Union this indicator is 32 objects, which is $40 \%$ higher than the value for Kharkiv [20].

For the period 2013-2016 there was an increase in the total capacity of the city's food supply network by $1.5 \%$ (from 123.8 thousand places to 125.7 thousand places). However, it should be noted that for the period 2013-2015 there was an increase in the value of this indicator by 3.1 thousand places (or $2.5 \%$ ). But in 2016 the trend changed to the opposite and the number of seats decreased by 1.2 thousand (or $0.7 \%$ ). Such changes in dynamics are of considerable interest and require further in-depth studies aimed at identifying the causes of the revealed negative trend and searching for methods to overcome it.

The actual provision of the city population with places in catering enterprises per 1000 people is 87 , which is twice the figure for the region [22]. In accordance with the standard for cities with a population of more than 1 million people, provision should be 75 places per 1000 people [25]. As can be seen from the obtained data, the actual value of this indicator for 12 places (or $16 \%$ ) exceeds the normative value. The audit of provision in places shows that the target value of the number of seats is 108.6 thousand, in fact there are 125.7 thousand in availability, which is 17.1 thousand (or $15.7 \%$ ) more. This fact can indicate both a satisfactory degree of development of the city's food supply network and the existence of competition between business entities.

The average capacity of the enterprises of the network decreased continuously and by the end of the study period the value of this indicator was 45.2 places or $96.5 \%$ of the initial one. In work [21] the tendency to integration of city's catering enterprises in the period of 2006-2009 was revealed. This was evidenced by the fact that the average capacity increased by $2.8 \%$ and amounted to 48.5 places during the studied period. A decrease in the value of this indicator by 3.3 units (or by $6.8 \%$ ) speaks in favor of the conclusion about the tendency to the disaggregation of catering enterprises.

The structure of the network of catering enterprises of any administrative-territorial unit is determined by the nomenclature of types of enterprises, the number of enterprises in terms of their types and the capacity of these enterprises. The term «type of enterprise» is understood to mean a set of common characteristic features of the production and trading activities of a catering enterprise [1]. Table 2 shows the audit data on the types of catering enterprises in Kharkiv on 01.01.2017 without taking into account specialized and procurement shops.

As can be seen from the data, at present in the city enterprises of all known types are subject to accounting, with the exception of the types «Snackbar», «Cafeteria», «House kitchen» and «Factory-kitchen». Ranking of types of enterprises by increasing their number in the total volume of the network leads to the following series: restaurant $\rightarrow$ special network $\rightarrow$ buffet $\rightarrow$ canteen $\rightarrow$ bar $\rightarrow$ cafe. At the same time, the smallest share in $3.5 \%$ is occupied by restaurants (97 facilities), the largest share in $44.2 \%$ at the cafe (1230 objects), and the integral share of cafes and 
bars is $60.8 \%$ (1.690 objects). This suggests that consumers enjoy a democratic format of service.

Table 2

The structure of the network of catering enterprises in Kharkiv in the context of their types (as of 01.01.2017)

\begin{tabular}{|c|c|c|c|}
\hline Type of the enterprise & Number, items & Share, \% & Rank \\
\hline Restaurant & 97 & 3.5 & 1 \\
\hline Cafe & 1230 & 44.2 & 6 \\
\hline Bar & 460 & 16.6 & 5 \\
\hline Canteen & 384 & 13.8 & 4 \\
\hline Buffet & 321 & 11.5 & 3 \\
\hline 5pecial network & 289 & 10.4 & 2 \\
\hline Total & 2781 & 100.0 & - \\
\hline
\end{tabular}

It is interesting to study the dynamics of the network structure. In [21], the Kharkiv network for the period 2006-2008 was investigated. The increase in the share of enterprises of the «Cafe» and «Bar» types was established. Summary data on the structure of the network for 2008 and 2016 are given in Table 3 .

Table 3

Dynamics of the structure of catering enterprises network in Kharkiv

\begin{tabular}{|c|c|c|c|c|}
\hline \multirow{3}{*}{$\begin{array}{c}\text { Type } \\
\text { of the enterprise }\end{array}$} & \multicolumn{4}{|c|}{ Years } \\
\hline & \multicolumn{2}{|c|}{2008 [21] } & \multicolumn{2}{|c|}{2016} \\
\hline & Number, items & Share, \% & Number, items & Share, \% \\
\hline Restaurant & 59 & 2.7 & 97 & 3.5 \\
\hline Cafe & 1026 & 46.4 & 1230 & 44.2 \\
\hline Ваг & 327 & 14.8 & 460 & 16.6 \\
\hline Canteen & 386 & 17.4 & 384 & 13.8 \\
\hline Buffet & 260 & 11.7 & 321 & 11.5 \\
\hline Special network & 155 & 7.00 & 289 & 10.4 \\
\hline Total & 2213 & 100.0 & 2781 & 100.0 \\
\hline
\end{tabular}

The data of Table 3 show that over the past time the total number of enterprises of the network has increased by $25.7 \%$ (from 2213 facilities in 2008 to 2781 facilities in 2016). At the same time, the share of restaurants, bars and special network enterprises increased by $0.8,1.8$ and 3.4 percentage points, respectively. At the same time, the share of cafes, canteens and buffets decreased by 2.2, 5.9 and 0.2 percentage points.

In order to clarify the importance of the established changes in the structure of the network, one can use the notions about the level of service that catering enterprises offer consumers. Such characteristics of the service as the degree of comfort, the level of service and the volume of services provided determine the characteristic «Class of the catering enterprise» [1]. Of all types of enterprises, only the «Restaurant» and «Bar» types are stratified into classes. The total share of such enterprises in 2008 was $17.5 \%$, in $2016-20.1 \%$, which is 2.6 percentage points (or by $14.9 \%$ ) more. Thus, it can be argued that there are significant changes in the structure of the city's food network. These changes are associated with an increase in the share of enterprises that, in addition to satisfying their nutritional needs, offer high-level services and organize leisure activities.
It is of practical interest to compare the trends identified with the state of the matter in other countries. Thus, in [26] the development of the restaurant industry in the Republic of Poland is investigated. It is shown that for the period 2000-2013 there was an increase in the number of restaurants by $90 \%$ and a decrease in the number of canteens by $41.9 \%$, which corresponds to the revealed trend for Kharkiv [21]. At the same time, the work recorded a decrease in the number of bars by $31.6 \%$, although an increase in their number was noted for the object of the audit. It should be noted the discrepancy in the name of the types of enterprises. Thus, in the Republic of Poland the type «Gastronomic station» is taken into account and the terms «Cafe» and «Buffet» are not used. This fact affects the evidence of a more in-depth audit in the direction of their incorrectness.

The audit data of such important characteristic of the power network as its power are given in Table 4. One of the expressions of the indicator «Capacity of the enterprise» is the number of seats in the trading halls [27].

Table 4

The structure of catering enterprises network in terms of the capacity of types of enterprises

\begin{tabular}{|c|c|c|c|}
\hline Type of the enterprise & Capacity, seats & Share, \% & Rank \\
\hline Restaurant & 8042 & 6.4 & 3 \\
\hline Cafe & 45868 & 36.5 & 5 \\
\hline Bar & 9683 & 7.7 & 4 \\
\hline Canteen & 52319 & 41.6 & 6 \\
\hline Buffet & 4082 & 3.3 & 1 \\
\hline 5pecial network & 5706 & 4.5 & 2 \\
\hline Total & 125700 & 100.0 & - \\
\hline
\end{tabular}

Ranking of types of enterprises by increasing the share of their capacity leads to the following series: buffet $\rightarrow$ special network $\rightarrow$ restaurant $\rightarrow$ bar $\rightarrow$ cafe $\rightarrow$ canteen. At the same time, the smallest proportion of $3.3 \%$ has buffets (4.082 places), the largest share in $41.6 \%$ of canteens (45.868 places).

There are several approaches to the classification of catering enterprises. One of them is based on the characteristic of the target contingent for the service [1]. In this aspect, it should be noted that the total share of the capacity of enterprises selling food and beverages for consumers, which are united by professional features (namely, canteens, buffets and a special network) is $49.4 \%$. The share of enterprises selling food and drinks for consumption on the spot with the organization of entertainment programs (namely, restaurants, bars and cafes) accounts for $50.6 \%$ of the total capacity of the city network. Such facts make it possible to formulate the assertion that at the moment the Kharkiv catering network is equally aimed both at provision of food services during working hours and at providing services outside of working hours.

Prior to the joint audit of the analytical indicators «Capacity share» and «Enterprise share», they were tested for their association. Since the verification of the distribution of data sets for normality gave a negative result (Fig. 2), the Spearman rank correlation coefficient was used. The calculated value of the statistic $R$ is equal to 0.6 for $p=0.21$. Thus, there is an insignificant correlation between the values of the investigated data sets. 

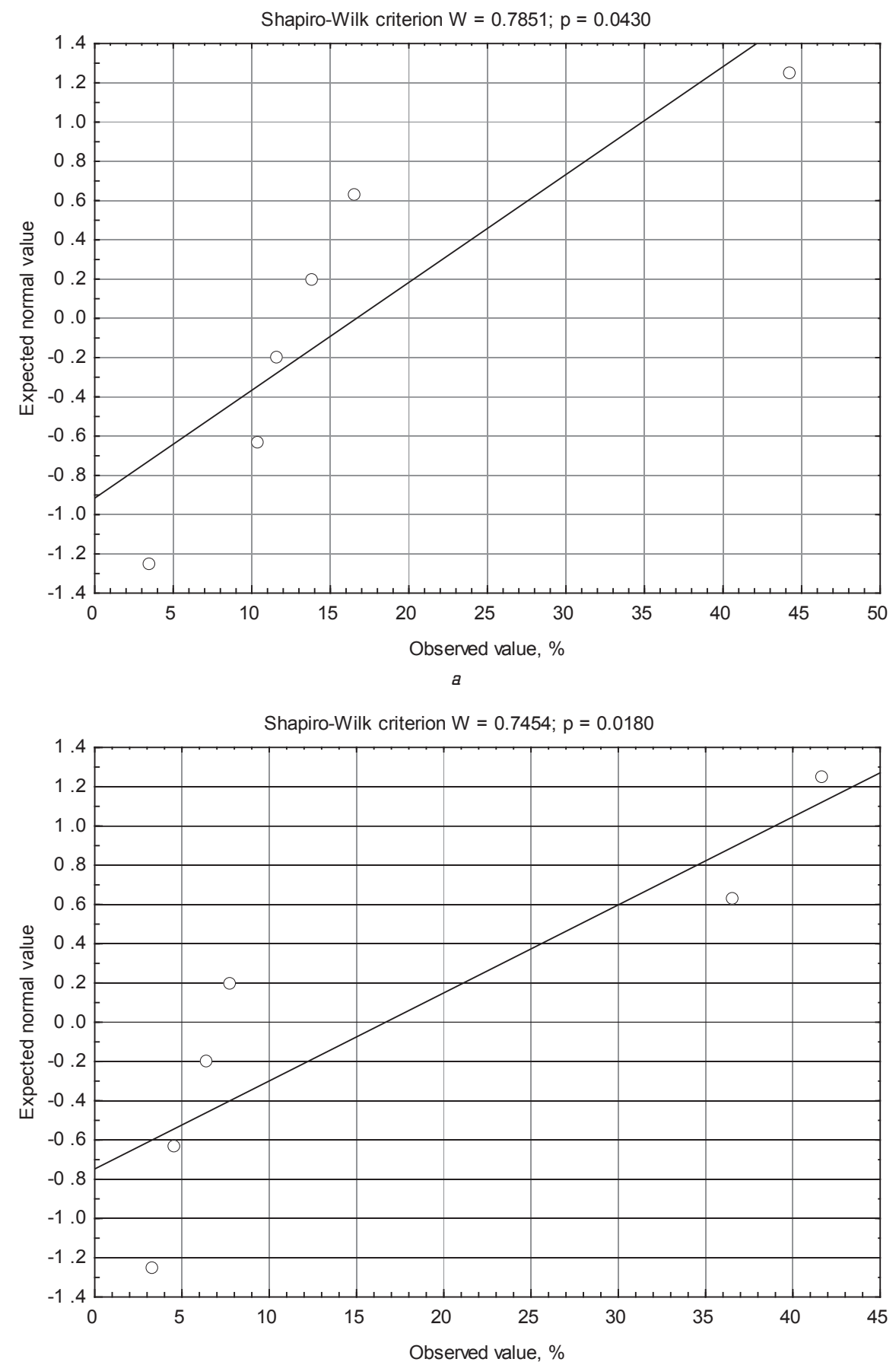

$b$

Fig. 2. Normal probabilistic graphs: $a$ - for the «Enterprise Share» data set; $b$ - for the «Power Share» data set

The joint graphical analysis of the analytical indicators «Capacity share» and «Enterprise share» (Fig. 3) revealed that for enterprises of the types «Restaurant» and «Canteen» the numerical value of the «Capacity share» index exceeds the numerical value of the indicator «Enterprise share» in 1.8 and 3.0 times, respectively. For the other types of enterprises, the opposite situation is observed.

To carry out a practically meaningful interpretation of this fact, an audit of the analytical indicator «Average capacity of enterprises by type» is conducted (Table 5).

In general, over the network, the average capacity of the enterprise is 45 places. For canteens and restaurants, this indicator is higher (136 and 83 places respectively), for other types of enterprises it is lower. Ranking of types of enterprises by increasing their average capacity leads to the following series: buffet $\rightarrow$ special network $\rightarrow$ bar $\rightarrow$ ca$\mathrm{fe} \rightarrow$ restaurant $\rightarrow$ canteen. At the same time, the integral share of enterprises with an average capacity that exceeds this figure by the network as a whole is $17.3 \%$. These facts allow to make a judgment that most of the city's catering enterprises are characterized by small shopping halls, oriented to creating a cozy atmosphere for leisure activities.

There is a classification of catering enterprises, based on the characteristic of the degree of service availability 
for potential consumers [1]. In accordance with it, enterprises are generally accessible and closed. In publicly accessible enterprises, products and services can be received by any consumer. Closed enterprises only service a certain contingent of consumers. However, the incompleteness of the secondary information used does not allow for a discriminatory audit between such enterprises within the boundaries of the scope of the audit object definition.

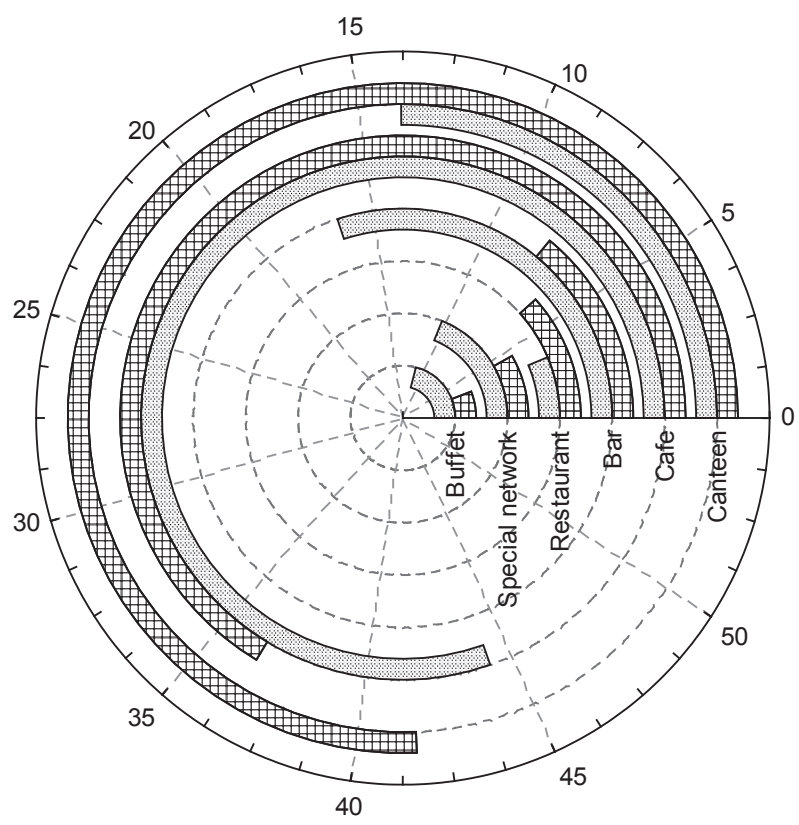

Enterprises, \% Capacity, \%

Fig. 3. The structure of the network in terms of types of enterprises and their capacity

Table 5

Characteristics of the network in terms of average capacity of enterprises

\begin{tabular}{|c|c|c|c|c|}
\hline $\begin{array}{c}\text { Type } \\
\text { of the enterprise }\end{array}$ & $\begin{array}{c}\text { Enterprise, } \\
\text { items }\end{array}$ & $\begin{array}{c}\text { Capacity, } \\
\text { seats }\end{array}$ & $\begin{array}{c}\text { Average } \\
\text { capacity, seats }\end{array}$ & Rank \\
\hline Restaurant & 97 & 8042 & 83 & 5 \\
\hline Cafe & 1230 & 45868 & 37 & 4 \\
\hline Bar & 460 & 9683 & 21 & 3 \\
\hline Canteen & 384 & 52319 & 136 & 6 \\
\hline Buffet & 321 & 4082 & 13 & 1 \\
\hline Special network & 289 & 5706 & 20 & 2 \\
\hline Total & 2781 & 125700 & 45 & - \\
\hline
\end{tabular}

\section{SWOT analysis of research results}

Strengths. The strength of the conducted research is the audit of the state of the public catering enterprise network in the city of Kharkiv, both in general by the organizational and technical indicators of the network, and also by type of enterprises. And also the identification and description of trends in the dynamics of the audit object for the period 2013-2016.

Weaknesses. The weak side of the obtained audit evidence is related to such structure of the investigated secondary information, which does not allow to stratify the objects of the city network to public and closed ones in a relevant way.

Opportunities. Opportunities for further audit activities are seen in an objective way in the study of the structure of the network of catering enterprises in the context of the administrative districts of the city with the study of its dynamics over a more or less prolonged time interval.

Threats. Threats to conclusions based on the received audit evidence can be manifested under the influence of variability in the socio-economic conditions of the external environment in which catering enterprises conduct their economic activities.

\section{Conclusions}

1. An audit of the state of the public catering network in Kharkiv for the period 2013-2016 is conducted, which provided evidence of the enlargement of the audit object. This is manifested in the growth of the number of enterprises and the increase in the total capacity of the network, expressed in terms of the number of seats in the trading holes. In this case, this trend is observed against the background of the weakening of the regional network of catering enterprises. Such phenomenon can find its explanation in the development of negative processes of humanitarian genesis, caused by fluctuations in the socio-economic environment.

2. The actual provision of the city with catering enterprises by 10 thousand people is three times higher than that for the region. At the same time, in the countries of the European Union, enterprises are $40 \%$ more provision. The actual provision of places in catering enterprises is twice as high as that for the region and $16 \%$ higher than the established standard. These facts can indicate both a satisfactory degree of development of the city's food supply network and the existence of competition between business entities.

3. A monotonous decrease in the average capacity of catering enterprises for the time interval studied is established, which supports the conclusion that there is a tendency for the disaggregation of catering enterprises.

4. Based on the study of the structure of the audit object, the types of enterprises are ranked by increasing their number in the total network volume. The received row has the following appearance: restaurant $\rightarrow$ special network $\rightarrow$ buffet $\rightarrow$ canteen $\rightarrow$ bar $\rightarrow$ cafe. This fact allows to make a judgment that the most common types of catering enterprises are cafes and bars with small shopping halls, oriented to creating a cozy atmosphere for leisure.

5. Ranking of types of enterprises by increasing their share of capacity has led to the following series: buffet $\rightarrow$ special network $\rightarrow$ restaurant $\rightarrow$ bar $\rightarrow$ cafe $\rightarrow$ canteen. At the same time, the total share of the capacity of enterprises selling food and drinks to consumers, united by professional features, is $49.4 \%$. Such facts make it possible to formulate the assertion that at the moment the Kharkiv catering network is equally aimed both at provision of food services during working hours and at providing services outside of working hours.

\section{References}

1. DSTU 4281:2004. Zaklady restorannoho hospodarstva. Klasyfikatsiia [Text]. - Introduced: 2004-07-01. - Kyiv: Derzhspozhyvstandart Ukrainy, 2004. - Part III. - 12 p. 
2. Mostova, L. M. Orhanizatsiia i proektuvannia zakladiv restorannoho hospodarstva [Text]: Handbook / L. M. Mostova, K. V. Svidlo, T. A. Lazareva. - Kharkiv: UIPA, 2012. - 351 p.

3. Pogadaeva, N. Yu. The study of the environment of public catering enterprises [Text] / N. Yu. Pogadaeva, E. A. Zavyalova // Bulletin of Kemerovo State University. Series: Political, Sociological and Economic sciences. - 2016. - No. 2 (2). - P. 88-92.

4. Mikkola, M. Green Connections and Emotional Wellbeing: Sustainability as a Factor of Occupational (Dis)Satisfaction in Catering [Text] / M. Mikkola, A. Post // Proceedings in System Dynamics and Innovation in Food Networks. - CentMa, Intern Center for Management, Communication, and Research, 2012. - P. 511-529. doi:10.18461/pfsd.2012.1237

5. Caputo, P. Food Chain Evaluator, a tool for analyzing the impacts and designing scenarios for the institutional catering in Lombardy (Italy) [Text] / P. Caputo, M. Clementi, C. Ducoli, S. Corsi, G. Scudo // Journal of Cleaner Production. - 2017. Vol. 140. - P. 1014-1026. doi:10.1016/j.jclepro.2016.06.084

6. Czarniecka-Skubina, E. Catering services in Poland and in selected countries [Text] / E. Czarniecka-Skubina, E. Rutkowska // Zeszyty Naukowe Uniwersytetu Szczecińskiego. Service Management. - 2015. - Vol. 15. - P. 13-22. doi:10.18276/smt.2015.15-02

7. Petruk, Yu. Actual tasks on restaurant businesses development management in Ukraine [Text] / Yu. Petruk // Skhid. 2014. - No. 4. - P. 41-47.

8. Gheribi, E. Factors Affecting the Development of Catering Enterprises in Poland [Text] / E. Gheribi // Ekonomiczne Problemy Turystyki. - 2015. - Vol. 31. - P. 207-220. doi:10.18276/ ept.2015.3.31-11

9. Kelly, P. W. The catering industry in the Republic of Ireland [Text] / P. W. Kelly // International Journal of Hospitality Management. - 1995. - Vol. 14, No. 1. - P. 25-37. doi:10.1016/0278-4319(94)00043-x

10. Nasretdinov, I. T. Current status and development trends of the market of public catering in Russia [Text] / I. T. Nasretdinov // Scientific notes of the Kazan State Academy of Veterinary Medicine named after N. E. Bauman. - 2015. - Vol. 222, No. 2. P. $162-166$

11. Tahtaeva, R. Sh. Sostoianie, problemy i perspektivy razvitiia infrastruktury turizma $v$ respublike Kazahstan [Text] / R. Sh. Tahtaeva // Obshchestvo. Sreda. Razvitie (Terra Humana). - 2013. No. 3 (28). - P. 29-34.

12. Perchinskaya, N. P. Innovations in Trade of Moldova [Text] / N. P. Perchinskaya, A. D. Duca // Innovations. - 2012. No. 10 (168). - P. 113-120.

13. Mayurnikova, L. A. Identification and analysis of catering development factors in the Kemerovo region [Text] / L. A. Mayurnikova, T. A. Scherbakova, T. V. Krapiva, N. I. Davydenko, S. V. Novoselov // Food Processing: Techniques and Technology. - 2015. - No. 4. - P. 169-174.

14. Kazakova, T. I. Research organizations of public catering Nizhny Novgorod [Text] / T. I. Kazakova // Bulletin NGII. - 2014. No. 7 (38). - P. 124-132.

15. Sosnina, A. A. The condition and the trends of the restaurant business development on the example of Novosibirsk [Text] A. A. Sosnina, S. I. Glavcheva // The Bulletin of KrasGAU. 2014. - No. 11. - P. 64-67.

16. Nikolaeva, I. V. Obzor rossiiskogo i Samarskogo rynkov obshchestvennogo pitaniia [Text] / I. V. Nikolaeva // Innovatsionnaia nauka. - 2016. - No. 11-1. - P. 119-122.

17. Maksimova, M. A. Development of the public catering enterprise market in St.-Petersburg in the conditions of the competition [Text] / M. A. Maksimova, O. S. Zybin // Technico-tehnologicheskie problemy servisa. - 2011. - No. 15. - P. 98-101.

18. Gavriliuk, M. V. Sovremennoe sostoianie i strategicheskie napravleniia razvitiia rynka uslug obshchestvennogo pitaniia oblastnyh gorodov (na primere g. Tver) [Text] / M. V. Gavriliuk, I. A. Soldatova // Servis v Rossii i za rubezhom. - 2012. No. 10. - P. 94-104.
19. Sabitov, R. Yu. The specificity of the activity of public catering establishments in the city Tyume [Text] / R. Yu. Sabitov // Omskii nauchnyi vestnik. - 2013. - No. 4 (121). - P. 45-48.

20. Mayurnikova, L. A. Analysis and prospects of catering market in regions [Text] / L. A. Mayurnikova, T. V. Krapiva, N. I. Davydenko, K. V. Samoylenko // Food Processing: Techniques and Technology. - 2015. - No. 1. - P. 141-147.

21. Anisimov, H. H. Analiz rozvytku zahalnodostupnoi merezhi restorannoho hospodarstva Kharkova [Text] / H. H. Anisimov, Ye. V. Zhukov // Visnyk Mizhnarodnoho slovianskoho universytetu. Seriia: Ekonomichni nauky. - 2009. - Vol. 12, No. 2. - P. 17-22

22. Hrosul, V. A. Tendentsii suchasnoho rozvytku pidpryiemstv restorannoho hospodarstva $\mathrm{v}$ Ukraini ta Kharkivskii oblasti [Text] / V. A. Hrosul, T. P. Ivanova // Scientific Bulletin of Uzhhorod University. Series «Economics». - 2017. - Vol. 1, No. 1 (49). - P. 143-149.

23. Baldigara, T. Tourism Statistics in Croatia: Present Status and Future Challenges [Text] / T. Baldigara, M. Mamula // Procedia - Social and Behavioral Sciences. - 2012. - Vol. 44. P. 53-61. doi:10.1016/j.sbspro.2012.05.004

24. Demohrafichni dani po Kharkivskii oblasti za sichen-traven 2017 roku [Electronic resource]: Statystychnyi biuleten (prezentatsiina versiia). - Kharkiv: Holovne upravlinnia statystyky u Kharkivskii oblasti, 2017. - Available at: \www/URL: http:// kh.ukrstat.gov.ua/upload/publikacii/prez_bul_dem_dani_05.17.zip

25. Pro zatverdzhennia Normatyviv zabezpechenosti mistsiamy v zakladakh restorannoho hospodarstva ta Poriadku zastosuvannia normatyviv zabezpechenosti mistsiamy $\mathrm{v}$ zakladakh restorannoho hospodarstva [Electronic resource]: Order of the Ministry of Economy of Ukraine No. 1111 from October 12, 2009. - Available at: \www/URL: http://zakon5.rada.gov.ua/laws/show/z1015-09

26. Prokopiuk, A. Some Current Trends of Restaurant Industry Development in Ukraine and Poland [Text] / A. Prokopiuk, Yu. B. Felenchak // Scientific Bulletin of UNFU. - 2015. Vol. 25.4. - P. 259-265.

27. DBN V.2.2-25:2009. Budynky i sporudy. Pidpryiemstva kharchuvannia (zaklady restorannoho hospodarstva) [Text]. - Introduced: 2010-09-01. - Kyiv: Minrehionbud Ukrainy, 2010. - 83 p.

\section{АУДИТ СОСТОЯНИЯ СЕТИ ОБЩЕСТВЕННОГО ПИТАНИЯ ГОРОДА ХАРЬКОВ}

Проведен аудит сети предприятий общественного питания города Харькова (Украина) за 2013-2016 гг. Рассмотрена динамика таких показателей, как количество предприятий, общая мощность сети, количество предприятий по типам, мощность предприятий, среднее количество мест в предприятиях. Сформулированы основные тенденции динамики объекта аудита. Проведено сравнение полученных доказательств аудита с нормативными требованиями и данными по состоянию сетей в других регионах страны и мира.

Ключевъе слова: предприятие питания, сеть предприятий, тип предприятия, мощность предприятия, обеспеченность населения.

Anisimov Genadiy, Department of Food Technologies and Hotel and Restaurant Business, Kharkiv Institute of Trade and Economics of the Kyiv National University of Trade and Economics, Ukraine, e-mail: avgyr1957@gmail.com, ORCID: http://orcid.org/0000-00020707-8666

Zhukov Yevhenii, PhD, Department of Food Technologies and Hotel and Restaurant Business, Kharkiv Institute of Trade and Economics of the Kyiv National University of Trade and Economics, Ukraine, e-mail: qsm@yandex.com, ORCID: http://orcid.org/00000002-8445-3490

Lipovoy Denis, Department of Food Technologies and Hotel and Restaurant Business, Kharkiv Institute of Trade and Economics of the Kyiv National University of Trade and Economics, Ukraine, e-mail:xteid@ukr.net, ORCID:http://orcid.org/0000-0002-9143-4896 